\title{
A FORJA DO MITO EM AS MOSCAS DE SARTRE
}

\author{
Leandro Neves Cardim ${ }^{1}$
}

\begin{abstract}
RESUMO: A peça de teatro As moscas, de Sartre, será abordada com o intuito de acompanhar o modo como seu autor reinventa o mito de Orestes, presente na tragédia grega. Sartre subscreve pontos de partida que nos fazem perceber que, em seu diálogo com a tradiçáo, ele trabalha com a liberdade no avesso da necessidade, o que termina invertendo a tradição. Ele adota certa concepção da relação entre o passado e o mundo atual que nos permite ler o mito de Orestes de tal forma que ele não exclui o passado, antes, o exige. Orestes não se faz do nada, sua ação não se estabelece através de uma simples continuidade com o passado. Trata-se de investigar a importância que o passado desempenha no interior dessa peça, assim como indicar, a partir desse ponto de vista, o lugar que nossas aquisiçóes devem ocupar no mundo atual.
\end{abstract}

PALAVRAS-CHAVE: Sartre. Teatro. Mito. Tradição. Atualidade.

Jean-Paul Sartre escreveu a peça de teatro As moscas, entre 1941 e 1942. Ela foi encenada pela primeira vez em 1943, sob a Ocupação, sob a ditadura e sob a colaboração de Pétain e de Vichy. Após a derrota militar de 1940, muitos franceses ficaram desencorajados e cheios de remorsos. A culpa da derrota da França estaria no passado, e o remorso, a vergonha, seriam as únicas condutas aceitáveis e honestas. Esse drama sartriano deve ser lido com este pano de fundo: obra de resistência que fura o bloqueio da censura nazista e emplaca, em meio à dominação do inimigo e à ditadura, um apelo radical à liberdade humana. Sua intenção era infundir coragem no povo francês. Ao invés de dar um passo para trás, aceitando o remorso, era preciso dar um passo para frente, em direção ao futuro. Em 1947, por ocasião de uma exibição da peça na Alemanha, Sartre esclarece isso em uma nota:

[...] o futuro - ainda que um exército inimigo ocupasse a França - era novo. Tínhamos poder sobre ele, éramos livres para fazer um futuro de vencidos ou, ao contrário, de homens livres que se recusam a crer que uma derrota marque o fim de tudo o que dá vontade de viver uma vida de homem.(SARTRE, 1992, p. 273) ${ }^{2}$

\footnotetext{
${ }^{1}$ Professor do Departamento e do Programa de Pós-Graduação em Filosofia da Universidade Federal do Paraná. E-mail: lnc@ufpr.br

2 SARTRE, J.-P. Les mouches. In: Un théatre de situations. Paris: Gallimard, 1992, p.273; obra citada com a sigla TS.

http://dx.doi.org/10.1590/S0101-31732017000400010
} 
Era em direção ao futuro que Sartre queria voltar os olhos da França ao escrever essa peça. Trabalhar nessa perspectiva equivalia a agir de maneira resistente e responsável. Para Sartre, o agente não é um joguete do destino, nem possui uma liberdade abstrata que se confundiria com o poder de sobrevoar a condiçáo humana. A dificuldade consiste em compreender como é que, sob as condiçôes mais duras que nos puxam para trás, a ação se torna radicalmente livre; ou como, agindo a partir do que já existe, construímos algo novo. Para investigar isso, pretendemos acompanhar o trabalho sartriano, o qual, do interior da tradição, inverte o seu sentido.

A atmosfera política da Ocupação - "[...] nunca fomos mais livres do

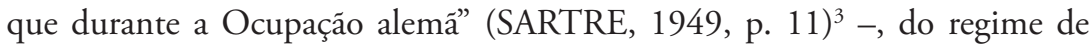
colaboração e, principalmente, da guerra, é de grande importância, porque Sartre escreve essa peça com o intuito de contribuir para a erradicação de uma enfermidade pública. Ele quer exterminar essa doença com alto nível de contaminação: a complacência com o arrependimento e a vergonha. Contra isso, era preciso “[...] reerguer o povo francês, lhe dar coragem.” (TS, p. 275). É para realizar tal tarefa que ele retoma um antigo mito grego, o mito de Orestes. Vários dramaturgos franceses também retomaram mitos da antiguidade, sob a Ocupação e mesmo antes da guerra. Mas a originalidade e o ganho dessa peça se encontram no fato de que, ao trabalhar esse mito tradicional, Sartre quer ir além da tradição. Ele forja um mito novo: o mito da liberdade de Orestes e de seu papel libertador. O mito trabalhado em As moscas gira em torno do lendário crime cometido por Orestes, o matricida e vingador de seu pai. Ésquilo, Sófocles e Eurípedes abordaram esse mito, cada um a seu modo, mas, como observa Grimal (2011, p. 339), “[...] a versão de Ésquilo é de longe a mais divulgada.” A propósito, é precisamente essa versão do mito que Sartre retoma, particularmente, a segunda parte da Oresteia, momento em que Agamenon, rei de Argos, já fora assassinado. Para efeito de contraste e com a intenção de pôr em relevo alguns traços do mito relativos ao papel do Destino e das açóes humanas, vale a pena delinear a estrutura e o enredo desse mito antigo.

A lenda arcaica de Orestes precede os trabalhos de Ésquilo; antes dele, os poetas já haviam abordado essa história trágica. Tudo se passa durante o ciclo mítico que gira em torno da guerra de Troia, ou melhor, do ciclo

${ }^{3}$ Nesse mesmo volume, conferir os artigos "Paris sous l'Occupation" e "Qu'est-ce qu'un collaborateur?" 
miceniano no qual se desenvolveu a civilizaçáo que cresceu em torno de Micenas, durante a Idade do Bronze. No primeiro livro da trilogia de Ésquilo, ao final da guerra, Agamenon volta para Argos e, sobre tapetes de púrpura, entra em seu palácio. Preso em uma rede durante o banho, o rei é assassinado a punhaladas pela rainha, Clitemnestra, e pelo seu amante, Egisto. $\mathrm{O}$ velho destino dos descendentes de Tântalo retorna: "as maldiçóes de antigas eras" voltam a pesar nos ombros dos descendentes de Atreu, o "anfitrião cruel". Novamente, a intrincada trama tecida pelo Destino e pela culpa vem à tona. A própria rainha se refere a esse Destino que assola sua família como a um "[...] gênio insaciável que persegue/inexoravelmente” os átridas: “[...] a sede atroz de sangue nos vem dele, enraizada em nosso próprio ser; / não foi curada ainda a chaga antiga/ e já feridas novas aparecem."(I, 1720-23, 76). ${ }^{4}$

Um pouco mais adiante e respondendo sarcasticamente a Clitemnestra o Coro, constituído por anciāos de Micenas, antecipa o desfecho: “[...] já o destino as armas da justiça/ afia para nova punição!” (I, 1785-86, 78). Mesmo antes que a rainha assassinasse Agamenon e Cassandra, esta, filha de Príamo e trazida de Troia como troféu de guerra, teve a oportunidade de profetizar à assassina que "[...] não há morte sem vingança de algum deus. / Virá um dia mais um vingador - o nosso - / nascido para exterminar a própria máe / e castigar a morte inglória de seu pai." (I, 1471-74, 66-67). Ainda que a fala de Cassandra náo tenha eficácia sobre seus ouvintes, ela contém uma ideia importante: o sangue atrai o sangue e, assim, a vingança atrai a vingança, infinitamente em um ciclo de morte e vingança. Ao fim desse primeiro livro, a rainha reconhece a fatalidade do crime, isto é, ela reconhece aí a realização de um fado já há muito tempo determinado e, entâo, aceita resignadamente os golpes do destino. Podemos imaginar a rainha se dando conta de algo que o Coro já havia dito antes: "[...] açôes iníquas geram fatalmente / iniquidades umas sobre as outras, / idênticas em tudo à sua origem; porém nas casas onde houver justiça / jamais filhos perfeitos faltarão.” (I, 855-59, 44).

No segundo livro, sete anos se passaram do assassinato do rei e da usurpação do trono. Orestes, o "exilado errante", filho de Agamenon e Clitemnestra, irmão de Electra, volta para Argos junto com um amigo, Pílades. Aos pés do túmulo de seu pai, ele vê um cortejo de mulheres se aproximarem e se esconde. Ocultos - Orestes e Pílades - eles ouvem o Coro

\footnotetext{
${ }^{4}$ ÉSQUILO. Oresteia: Agamêmnon, Coéforas, Eumênides. Tradução de Mário da Gama Kury. Rio de Janeiro: Zahar, 2010, Livro I, versos 1720-23, p.76; obra citada pelo número do livro, dos versos e página da tradução.
} 
dizer que a maior infelicidade de um culpado é a demora pelo castigo, porém, "[...] a balança/da justiça serena está atenta." (II, 75-76, 93). Ao culpado está reservada "[...] a ruína total e completa" (II, 89, 93) e não há como escapar aos "[...] duros golpes do destino cego." (II, 106, 94). Entre as portadoras de oferendas ou entre aquelas que fazem as libações - as Coéforas - está Electra. Depois de se reconhecerem, Orestes conta a Electra a determinação do Oráculo de Apolo: vingar a morte do pai, punindo os homicidas, exterminálos. Caso não obedecesse, Orestes seria duramente punido com a morte em meio a muito sofrimento, mas antes ele seria castigado com pragas terríveis e com os "[...] ataques horrorosos/ das Fúrias." (II, 372-3, 104). As Fúrias ou as Erínias eram personificaçóes do remorso que deviam vingar os crimes de morte contra os consanguíneos. Não há saída para o criminoso que tem as Erínias em seu encalço, afinal, elas são verídicas, jamais esquecem os crimes e sempre cumprem a vingança de maneira eficaz. Para levar a cabo a vingança, elas exalam sobre o culpado um "sangrento hálito" que o resseca "com o vapor de fogo", o qual sai, de maneira insuportável, de suas entranhas; elas extenuam a vítima até retirar-lhe completamente o fôlego "[...] numa perseguição feroz e implacável." (III, 185-90, 152-53).

Orestes sabia de tudo isso, ainda assim, o imenso peso do "onipotente oráculo de Apolo" o conduz a enfrentar o destino trágico de sua família. Mesmo se não desse crédito ao "mandamento nítido de Apolo", a vingança se consumaria. Havia a dor pela morte do pai, a ameaça de pobreza e o desejo de não deixar os concidadãos vencedores em Troia serem escravizados. Em todo caso, era preciso aplicar o castigo ao culpado. ${ }^{5}$ Em uma situação como essa, lutar contra a lei inflexível da fatalidade é razão para desesperar-se. Por isso, embora sabendo que vai morrer, Orestes decide matar a máe e o usurpador do trono. Orestes vinga seu pai. A "força do Destino inexorável” é implacável. Ali, no último momento, Orestes ainda hesita, mas seu amigo não o deixa esquecer que "[...] seria melhor/obedecer aos deuses que a todos os homens!" (II, 1152-53, 132). ${ }^{6}$ Consumados os assassinatos, o assassino começa a ser perseguido pelas Erínias e foge para Delfos, esperando a intercessão de Atena a

\footnotetext{
${ }^{5} \mathrm{O}$ pedido do porta-voz do Coro ecoa a antiga Lei de Taliáo - olho por olho, dente por dente- e o mais antigo ainda Código de Hamurabi: "Parcas potentes, peço-vos por Zeus: / fazei com que tudo se realize / no rumo seguido pelo destino! / Fazei com que a cada palavra de ódio/ responda logo outra palavra igual, / como a justiça quer ao exigir; em altos brados a reparação! / Contra cada golpe mortal desfira-se / um novo golpe igualmente mortal! / 'Ao culpado o castigo', diz o adágio/ há muito tempo ouvido e repetido!” (II, 408-18, 105).

“A hesitação de Orestes deve, no máximo, ser interpretada, como faz Rivier, como um "escrúpulo" que "[...] não coloca em questão sua decisão": esse escrúpulo faz Orestes "[...] experimentar mais vivamente
} 
seu favor. O segundo livro termina com uma questão a que o terceiro livro se encarrega de dar um desenlace: "Onde se deterá, ou findará, / a Ira precursora da Vingança?” (II, 139-40, 141).

\section{O último livro é o julgamento de Orestes. Ele foge de Argos para Delfos} e daqui para Atenas, sendo ao mesmo tempo perseguido pelas implacáveis Erínias e protegido por Apolo. Orestes se refugia no templo de Apolo, o qual, astutamente, o protege. Inicialmente, a própria deusa Atena se recusa decidir a favor de Orestes, momento em que Atena institui e preside o primeiro tribunal humano para discutir a questáo: os juízes ficam divididos meio a meio e, finalmente, a deusa, cujo voto vale por dois, decide em favor de Orestes. Ao contrário de ser condenado, Orestes é absolvido. Quanto às Erínias, Atena termina convencendo-as a proteger a cidade de Atenas e se tornarem, agora, as benevolentes (as Eumênides). Elas aceitam o compromisso e a peça termina com hinos do povo louvando "[...] a união entre as Parcas e Zeus onividente." (III, 1367-68, 194). As deusas que tecem os destinos e a sina dos homens e o deus que está acima de todos mantém a ordem no universo e sabe tudo o que acontece, o deus que guia os homens no caminho da sabedoria - e que "[...] decretou a regra para sempre certa:/ 'o sofrimento é a melhor lição"” (I, 211$12,25)$-, terminam unidos. ${ }^{7}$

Nessa retomada do mito na tragédia de Ésquilo, procuramos enfatizar

a 'necessidade', isto é, a ação imperativa das potências que o incitam e o impelem a realizar o crime." (RIVIER, 1968, p. 36).

7 Como observa Blanchot, em um artigo sobre a peça de Sartre, o drama grego de Ésquilo "[...] ilustra a passagem de um mundo a outro, do mundo das divindades subterrâneas ao dos deuses do dia, das sombras potentes do medo e do sangue aos poderes superiores cuja soberania supóe com o homem uma verdadeira união subjetiva. [...] A sentença restitui Orestes a sua inocência, mas, com mais força ainda, consagra a jovem potência dos deuses novos, confirma sua amizade com o homem e anuncia um novo equilíbrio que a submissão às potências da noite não corre mais o risco de romper." (BLANCHOT, 1971, p.73). Para avançar na interpretação dessa passagem de um mundo a outro, vale a pena lembrar o estudo de Bachofen: $O$ direito materno (1861). Nessa obra, ele lê a passagem em questão nos termos de uma oposição entre os sexos. Segundo Vernant, Bachofen foi o primeiro a perceber a natureza do problema que envolve o matricida, "[...] mas interpretou historicamente este conflito - como se, a um matriarcado primitivo houvesse sucedido um direito masculino." Ainda conforme Vernant, o sentido desse conflito deve ser procurado menos na oposiçấo social e institucional, e mais na oposição psicológica da luta do filho com a máe. O problema está no contraste entre a ordem superior do oráculo e a loucura que envolve o matricida. Náo se trata de negar o fato de que o mito do matricídio ponha em jogo uma "oposiçáo dos sexos", mas sim de frisar que "[...] essa oposição encarna-se sempre em instituiçôes familiares, em condutas sociais definíveis. [...] $\mathrm{O}$ mito parece-nos menos traduzir a oposiçấo entre masculino e feminino em geral do que estilizar e dramatizar os conflitos inerentes a estruturas sociais definidas." (VERNANT, 2009, p. 277-280). Em suma, a lição de Vernant está em que, no estudo desse mito, é preciso dar ênfase não à separação, mas à relação entre o psicológico e o social, afinal, um é parte do outro. 
ao mesmo tempo a força do Destino conjugada com a sabedoria de Zeus e a complexidade das ações e das paixóes humanas. Isso é indispensável, porque o leitor da peça sartriana reconhece imediatamente a estrutura e os personagens da tragédia antiga. $\mathrm{Na}$ verdade, isso faz parte da intenção do autor, pois ele mesmo diz que "[...] retoma a armadura e conserva os personagens" (TS, 268) da tragédia. Segundo Sartre, "a grande tragédia” - Ésquilo, Sófocles, Corneille - tem como força propulsora a liberdade humana: "[...] a fatalidade que cremos constatar nos dramas antigos é o avesso de sua liberdade. As próprias paixóes são liberdades em relação a sua própria armadilha." (TS, 19). Em contraste com o teatro psicológico de Eurípedes e Voltaire, precisamos aproveitar as "[...] virtudes e os vícios da tragédia": "[...] a vontade, o juramento, a loucura do orgulho" (TS, 19). Sartre faz questáo de frisar que essa consideração da paixão no interior de um projeto integral que o homem faz de si mesmo deve encontrar sua inspiração na tragédia grega. É isso que ele exibe no teatro: um personagem que é impossível de ser compreendido sem que a dimensão mais ampla de sua ação esteja enraizada naquilo que há de mais próprio em uma determinada situação.

Vejamos a reescritura do mito no drama sartriano concebido para ser encenado em três atos. ${ }^{8}$ No primeiro ato, acompanhado de perto pelo Pedagogo e à distância por Júpiter disfarçado de um homem chamado Demétrio, Orestes, também disfarçado de um jovem proveniente de Corinto chamado Filebo, chega a uma praça de Argos, cidade governada por Egisto, o qual reina impondo o medo e a penitência aos cidadãos. Passados quinze anos, Orestes volta e encontra um povo arrependido por náo ter feito nada para impedir o crime; e, coisa ainda muito mais terrível, o povo parece gostar de ser dominado pelo medo dos mortos. Acolhido pelas moscas e logo em seguida por Demétrio, este lhe dá algumas explicações: as moscas são símbolo da culpa, elas foram atraídas para a cidade por um "forte cheiro de cadáver". As moscas perseguem os habitantes de Argos, todos eles ainda vestidos de luto por causa da morte de Agamenon, todos eles educados no arrependimento, todos eles com as mãos sujas de sangue. Júpiter mostra como afastar as moscas:

\footnotetext{
8 Peça dirigida e montada por Charles Dullin, em 1943. A peça foi apresentada no antigo Théâtre Sarah Bernardt, rebatizado com o nome Théâtre de la Cité, por causa da origem judia da atriz; vale acrescentar que essa peça é dedicada a Dullin e que o ano de sua publicação coincide com o de $O$ ser e o nada.

9 SARTRE, Jean-Paul. Huis clos. Suivi de Les mouches. Paris: Gallimard, 1947; para as citações em nosso texto, utilizamos a versão brasileira As moscas. Tradução de Caio Liudvik. Rio de Janeiro: Nova Fronteira, 2005, p.7; obra citada com a sigla M.
} 
ele mexe com os punhos e os braços e diz uma fórmula mágica - "abraxas, gala, gala, tsé, tsé" - e as moscas somem. Orestes começa, então, a questionar as liçôes do Pedagogo, o qual havia lhe ensinado a ser um cético sorridente e a ter liberdade de espírito. A liberdade que, por enquanto, Orestes possui o faz leve, ele pensa que não é nada além de uma liberdade vazia, permanecendo fora do mundo: “[...] não peso mais que um fio e vivo no ar." (M, 17). Porém, o que ele quer é encontrar um ato que lhe dê direito de cidadania para viver entre os cidadãos de Argos. Ele inveja os homens que nascem engajados. Demétrio conta a história de Argos e antecipa o estado de miséria e humilhação de Electra. Ainda disfarçado, Orestes encontra Electra, a qual conta que teve o pai assassinado, a mãe no leito do assassino e que foi escravizada; todavia, ela não foge, porque espera algo ou alguém. Surge, entáo, Clitemnestra, obrigando-a a preparar-se para a festa fúnebre que exige trajes de luto. A rainha termina confessando à filha e a Orestes, ainda disfarçado, que não se arrepende do assassinato do rei, mas sim de ter permitido que Egisto levasse seu filho quando pequeno e o vendesse a mercenários. Ainda acompanhado de Demétrio, Orestes permanece na cidade para seguir os cerimoniais da festa religiosa em que os mortos voltam para atormentar os vivos e fazê-los pagar suas dívidas.

O segundo ato inicia-se com a cerimônia de medo e pavor da festa dos mortos. O Sumo Sacerdote invoca os mortos em nome da cólera, da amargura e do espírito de vingança: "[...] vinde saciar vosso ódio sobre os vivos! [...] Olhai, os vivos estão ali, gordas presas vivas! De pé, atirai-vos sobre eles em turbilhão e comei-os até os ossos! De pé! De pé! De pé!!!” (M, 43). Egisto lembra ao povo seus crimes e, com isso, atiça mais o medo e o terror. Chegando depois de iniciada a festa, Electra aparece vestida de branco: ao contrário do luto, ela quer inspirar alegria e esperança no seu povo. Egisto se enfurece, exilando-a. Em conversa com Orestes ainda disfarçado, ela diz esperar seu irmão que é neto de Atreu e não pode escapar ao destino dos átridas. Electra insiste que ele virá, pois "[...] tem o crime e a dor no sangue", como ela: Orestes "[...] está preso ao seu destino como cavalos estripados que tivessem as patas amarradas ao intestino, e que não pudessem mais se mexer sem arrancar as entranhas." ( $M, 55)$. Ele então se revela: "Electra, eu sou Orestes." (M, 56). Ele não importa quão alto será o preço que terá de pagar. Mesmo assim, ele quer assumir sua história, seu lugar em meio dessa gente que ele nunca deveria ter abandonado, ele quer inserir-se na cidade e assumir as condiçóes de um habitante de Argos: "Pouco me importa a felicidade. Quero minhas lembranças, meu solo, meu lugar entre os homens de Argos. [...] Quero ser 
um homem de algum lugar, um homem entre homens. [...] Quero estender a cidade em volta de mim e me enrolar nela como se fosse um manto." (M, 58-59). Orestes se dá conta de que "há um outro caminho" (M, 61): o seu caminho. Como encontrar esse caminho? Ora, ele pode dar à sua vida o peso e o sentido que tanto anseia, com "[...] o lastro de um crime bem pesado" (M, 62). Orestes abandona a leveza de sua juventude e decide livrar sua cidade do remorso e da culpa. Juntos, Orestes e Electra decidem executar os criminosos. Uma vez dentro do palácio e escondidos atrás do trono do rei, Orestes e Electra ouvem uma conversa de Egisto e Clitemnestra: o assassino se lastima e teme o morto. Mesmo tendo inventado essas fábulas com a intenção de dominar o povo, agora, ele mesmo teme Agamenon. Mas Egisto se sente mais morto que o próprio morto. Júpiter vem encontrá-lo na sala do trono e advertir-lhe do perigo iminente. Todavia, Egisto simplesmente se recusa a fazer qualquer coisa para livrar-se e nega-se a ouvir os conselhos de Júpiter, que tinha interesses próprios em evitar o crime. Quais interesses? O crime de Egisto servia a Júpiter no próprio ato da expiação da culpa. ${ }^{10}$ Júpiter fica exasperado com o crime que se anuncia e manda Egisto chamar os guardas. Diz odiar esses crimes dessa "nova geração", por causa de sua ingratidão e esterilidade: são como "a erva daninha”. O crime anunciado de Orestes é metódico, planejando com cabeça fria e de forma modesta; é um assassinato sem remorso, ele é insolente e calmo. Júpiter quer impedir esse crime e, apelando à consciência de rei de Egisto, ao amor que ele tem por reinar, ao fato de que "um rei é um Deus sobre a terra", que ambos fazem reinar a ordem, e que, enfim, "[...] o mesmo segredo pesa fundo em nossos corações” [de Egisto e de Júpiter], Júpiter nos revela não só um, mas dois segredos: o primeiro é "[...] o doloroso segredo dos deuses e dos reis: é que os homens são livres." (M, 76). O segundo é que, "[...] uma vez que a liberdade explodiu na alma de um homem, os deuses nada podem contra ele." (M, 78). No momento em que Orestes ataca Egisto, este se deixa assassinar. Com a hesitação de Electra, Orestes vai sozinho ao quarto da mãe e a executa; ele enfrenta a maldição que ronda o matricida assim como o castigo que lhe é atribuído, ele transgride a proibição sagrada. Quando retorna à presença de Electra, diz a ela que estão, finalmente, em plena "aurora de

\footnotetext{
${ }^{10}$ Júpiter diz a Egisto: "É porque tu o expias que ele me serve; eu amo os crimes que se pagam. Amei o teu porque foi um assassinato cego e surdo, ignorante de si mesmo, à moda antiga, mais parecido com um cataclismo do que com uma iniciativa humana. Não perdeste tempo me desafiando: mataste movido pela fúria e pelo medo; e quando a febre abaixou, consideraste teu ato com horror e não quiseste reconhecê-lo. Mas quanto proveito eu tirei dele! Para um homem morto, vinte mil outros mergulhados no arrependimento, eis o balanço. Não foi um mau negócio.” (M, 75).
} 
um novo dia" e que seu ato livre é responsável e consequente. ${ }^{11}$ No entanto, Electra não se reconhece na ação de Orestes, pois ainda não se sente livre e as moscas já começam a atormentá-los. Eles fogem para o templo de Apolo e lá se refugiam. Durante a noite, em sonhos, as moscas já os perseguem.

No último ato, no interior do templo, os irmáos se desentendem e Electra acaba se arrependendo e caindo nas garras das moscas, ela se entrega a Júpiter, que aparece sem disfarce. Seu irmão a pede que não deixe ninguém decidir em seu lugar e acrescenta: "Por que deformar um passado que náo pode mais se defender?” ( $M, 99)$. Já Orestes está só como um leproso, porém, ele não é um covarde, não tem remorsos, nem pesar: "[...] eu sou livre. Para além da angústia e das lembranças. Livre. E de acordo comigo mesmo.” (M, 94). Júpiter admoesta Orestes a arrepender-se, mas este não se considera culpado e, precisamente por isso, Júpiter não pode fazê-lo expiar algo que não reconhece como crime, por isso mesmo ele se considera inocente. Ele também recusa o trono de Argos. Orestes também não se deixa impressionar com os poderes sobrenaturais de Júpiter, o qual ainda o insulta de intruso - "[...] estás no mundo como um espinho na carne ou como um penetra que caça na floresta de outrem" (M, 101) -, de "verme no universo", e diz: "[...] o universo te desaprova." (M, 102). Júpiter ainda chama Orestes de "filho desnaturado" e o aconselha a voltar à natureza: "[...] reconhece tua culpa, abomina-a, arranca de ti como um dente cariado e fétido." (M, 102). Orestes não se deixa abalar: Júpiter é rei dos deuses, mas não rei dos homens. Orestes não é nem senhor nem escravo: "[...] eu sou minha liberdade!" (M, 103). A liberdade desaba sobre ele e o deixa em transe. Nesse momento, ele deixa sua juventude para trás: "[...] a natureza saltou para trás, e eu não tive mais idade, e eu me senti completamente só, [...] como alguém que perdeu sua sombra." (M, 104). Júpiter não desiste: ele menospreza a liberdade de Orestes - “[...] sarna que te dá comichão, não passa de um exílio!” (M, 104). Orestes, por sua vez, não quer dar-se outra lei senão a sua: “[...] estou condenado a não ter outra lei senáo a minha." (M, 105). A natureza com seus mil caminhos conduz, ela também, a Júpiter; e Orestes náo pode seguir senáo o seu caminho: “[...] pois eu sou um homem, Júpiter, e cada homem deve inventar seu caminho. A natureza tem horror ao homem, e tu, tu, soberano dos deuses, tu também tens horror aos homens." (M, 105). O peso da liberdade esmaga a leveza de sua

${ }^{11}$ Orestes continua: "Somos livres, Electra. Sinto que te fiz nascer e que acabo de nascer contigo. [...] Sou livre, Electra; a liberdade desabou sobre mim como um raio. [...] Eu fiz meu ato, Electra, e este ato era bom. Eu o carreguei sobre meus ombros como um barqueiro leva os viajantes, eu o farei passar para a outra margem e prestarei contas por ele. E quanto mais pesado para carregar ele for, mais me alegrarei, pois minha liberdade é ele." (M, 82-83). 
juventude: essa liberdade era o peso que faltava, agora ela lhe "[...] pesa na alma como chumbo" e, finalmente, seus "[...] pés afundam na terra como as rodas de um carro na trilha." (M, 107). Orestes encontra seu "precioso fardo" (M, 107) e, completamente só, deve ir rumo a si mesmo decidido a "abrir os olhos" (M, 105) dos homens de Argos.

Enquanto isso, fora do templo, o povo exige a presença de Orestes, o qual acaba saindo e dirigindo a seu povo a palavra. Ele fala à multidão, ele lhes dirige um discurso: "[...] sou Orestes, vosso rei, o filho de Agamenon, e este é o dia de minha coroação." ( $\mathrm{M}, 111)$. O povo fica amedrontado e Orestes reivindica seu crime à luz do sol perante todos, pois ele é sua razáo de viver, seu orgulho: crime cometido em seu nome e em nome dos cidadãos de Argos. Agora, as moscas se desinteressam dos cidadãos e se voltam para Orestes, o qual decide se exilar, porque náo quer ser rei de Argos: "[...] quero ser um rei sem terra e sem súdito.” ( $M, 112)$. Orestes começa sua despedida com um conselho: "[...] tentai viver: tudo é novo aqui, tudo está começando. Para mim também a vida começa. Uma estranha vida.” (M, 112). Em seguida, ele fica de pé e sai contando uma história ao povo, a história do flautista que fez com que os ratos da cidade o seguissem, libertando assim a cidade dos ratos; tanto o flautista quanto os ratos desaparecem para sempre, da mesma forma Orestes e as moscas. Orestes liberta a si mesmo e a cidade com seu crime: ele livra a cidade das moscas, que, agora, estão em torno dele e não mais do povo, pois, como nos diz a indicação cênica, Orestes sai e as moscas "[...] se lançam, aos gritos, atrás dele.” $(\mathrm{M}, 112) .{ }^{12}$

\footnotetext{
${ }^{12}$ Ao final da peça, Sartre liga, através da ação de Orestes, o homem à angústia, por intermédio da liberdade: as moscas se lançam aos gritos atrás de Orestes. Para compreender isso, é preciso acompanhar Blanchot,quando ele insiste no fato de que o ato livre de Orestes é um "ato paradoxal", porque Orestes sabe que sua liberdade está ligada às consequências que ele terá de assumir. Blanchot chama a atenção, ainda, para o fato de que a autenticidade do tema que aborda a morte da ordem e dos deuses, quando um homem se descobre livre, nos reenvia ao personagem de Dostoievski - Aleksej Kirillov - presente no livro Os demônios. Blanchot não menciona, mas há ainda outro personagem de Dostoievski que vale a pena ser mencionado, nesse contexto. Em alguns pontos, talvez esse personagem seja até mais representativo das convergências com Orestes sartriano. Trata-se de Ivan Karamázov, da obra Os irmãos Karamázov. Há uma famosa paráfrase de um trecho desse livro, que Sartre não só conhecia, como também cita nos seus Cadernos de uma guerra estranha, na quinta-feira, dia 07 de dezembro de 1939: "Se Deus não existe, tudo é permitido" (SARTRE, 1983, p.138). O trecho do livro de Dostoievski de onde surgiu a paráfrase é longo demais para ser aqui reproduzido (DOSTOIEVSKI, 2008, p.109110). Mas o sentido da apropriaçăo sartriana está em que é possível ao mesmo tempo detectar a retomada de certa tradição literária e indicar a presença do problema da moral. Excluída a objetividade das leis, das normas e dos valores, resta que o lugar da moral deve ser encontrado sobre a terra, nas relaçôes humanas. Uma vez sem a transcendência,exista Deus ou não, “[...] a moral é um negócio 'entre homens' e Deus não deve meter o nariz onde nâo é chamado. A existência da moral, ao contrário,
} 
Nessa peça, Sartre trabalha com certa concepção de relação entre a tradiçáo e o seu mundo atual, a qual deve ser posta em relevo: ele retoma o mito de Orestes, atribuindo-lhe um sentido atual. Vimos que Orestes, do interior de uma determinada situação e através dela, toma a decisão de matar sua mãe. Ora, é justamente isso que essa peça quer mostrar, pois, se é verdade que "[...] o homem é livre em uma situação dada e que ele se escolhe a si mesmo na e pela situação, então, é preciso mostrar no teatro situaçôes bem simples e humanas, e liberdades que se escolhem nessas situaçóes." (TS, 20). O que em As moscas podemos ver é que Orestes responde ao apelo daquilo que o cerca. Ele se sente táo concernido por sua situaçáo que, para ele, seria bom se estivesse "[...] dentro de sua cidade, como uma folha na folhagem, como a árvore na floresta." (M, 59). Sua situaçáo lhe propóe poucas opçóes e ele se decide pela mais radical e incerta. Sartre encena essa relação da decisão particular de Orestes com a totalidade do homem, através de certas "situaçóeslimite" que são justamente aquelas que "[...] apresentam alternativas dentre as quais a morte é um dos termos." (TS, 20). Aqui, a liberdade está em seu ápice, porque tudo pode dar errado, mas também pode dar certo. E, se for este o caso, é porque o teatro disse ao que veio: o teatro "[...] realiza a unidade de todos os espectadores" (TS, 20), ele "unifica o público diverso que o frequenta hoje" [novembro de 1947]. (TS, 21). Para fazer isso, o dramaturgo deve "[...] mergulhar os homens em situaçóes universais e extremas que não os deixam senão um par de opçóes." (TS, 20). Nessa peça, Sartre faz com que Orestes, ao tomar a decisão de cometer seu crime, escolha ao mesmo tempo a si mesmo e ao povo. Orestes liberta-se ao libertar seu povo, seu ato estabelece laços de sangue entre ele e os cidadãos de Argos. De uma situação particular nasce a liberdade radical de Orestes; e, para acompanhar o amadurecimento da ação, sua realização e consequências, é preciso, então, imaginar - e, no caso da peça, ver! - Orestes em uma situação tão comum que todos nós pudéssemos experimentá-la: "O que o teatro pode mostrar de mais emocionante é um caráter se fazendo, o momento da escolha, a decisão livre que engaja toda uma vida. [...] E como só há teatro se realizamos a unidade dos espectadores, é preciso encontrar situaçóes tão gerais que elas sejam comuns a todos." (TS, 20). Quem é esse Orestes que decide em situação e que essa peça nos ajuda a conhecer? Ele é alguém que deve perseguir seu próprio caminho inteiramente só: "Como qualquer um!" (TS, 267). O teatro de Sartre apresenta personagens

longe de provar Deus, o mantém a distância, porque é uma estrutura pessoal da realidade humana." (SARTRE, 1983, p. 138). 
que são “[...] liberdades presas em armadilhas, como todos nós!” (TS, 290) 13

Orestes não é um personagem real: o teatro não se ocupa com a realidade no sentido próprio da palavra. Não é a particularidade de Orestes que interessa a Sartre, mas seu drama. Em uma entrevista, ele nos diz que o teatro não deve se ocupar com a realidade, mas com a verdade: "[...] o verdadeiro campo de batalha do teatro é aquele da tragédia, drama que encerra um mito autêntico." Assim, o teatro deve investigar a verdade através do mito e "[...] utilizar formas não realistas como a tragédia.” (TS, 167). Para entender a especificidade da tragédia sartriana, é preciso dizer que ela é uma tragédia da liberdade, em oposição a uma tragédia da fatalidade (TS, 268). Não se trata, porém, de dizer que a tragédia de Ésquilo não seja uma tragédia da libertação ou da liberdade; aliás, precisamente por aí seria possível retraçara convergência. ${ }^{14}$ Entretanto, a distância entre Orestes concebido à maneira grega e à maneira sartriana pode ser percebida através daquilo que caracteriza o sentido do drama, da ação e da conduta do personagem em relação ao destino. Com uma pergunta, Sartre resume o que está sendo discutido ali: "Como se comporta um homem em face de um ato que ele cometeu, do qual ele assume todas as consequências e as responsabilidades, mesmo se, aliás, este ato lhe horroriza?" (TS, 268).

Lembremos: a ação de Orestes se dá na cidade de Argos e o sentido de seu crime não pode estar dissociado do destino de Argos. Isso significa que Sartre retoma a tragédia grega e inverte seu sentido. Afinal, é o comportamento de Orestes que importa ressaltar: em primeiro lugar, ele pode nos ajudar a reconhecer o papel da adversidade na ação humana; em segundo, ele pode nos dar a pensar sobre como podemos nos comportar em situaçóes adversas.

\footnotetext{
${ }^{13} \mathrm{O}$ interesse sartriano - a moral - vem à tona na sequência desta passagem: "Quais são as saídas? Cada personagem será apenas a escolha de uma saída e não quererá nada além que esta saída. É desejável que a literatura inteira torne-se moral e problemática, como este novo teatro. Moral - não moralizadora: que ele mostre simplesmente que o homem é também valor e que as questốes que ele se póe são sempre morais. Sobretudo que ela mostra nele o inventor. Em certo sentido, cada situaçáo é uma ratoeira, muros por todos os lados: exprimo-me mal, não existe saída para escolher. Uma saída, isto se inventa. E cada um, ao inventar sua própria saída, inventa-se a si mesmo. O homem tem que ser inventado todos os dias." (TS, 290.

${ }^{14}$ A passagem de um mundo a outro de que falou Blanchot, a propósito da Oresteia, deve suscitar "[...] a possibilidade para o homem de uma inocência nova"; é por aqui que encontramos a convergência entre "[...] o sentido que Sartre quer introduzir no mito antigo e os símbolos tradicionais a que estão ligados.” O esquema e os temas da tragédia de Sartre trabalham na mesma direção que os mesmos temas da tragédia antiga. Porém, se percebemos alguma "[...] dissonância entre a obra e o mito que ela ressoa, esta ruptura [...] [vem] da coincidência extraordinária que permitiu a um pensamento inteiramente novo juntar-se a verdade antiga com um mínimo de mudança e que torna, em seguida, mais sensíveis as discordâncias e as diferenças de expressão." (BLANCHOT, 1971, p.73, grifos nossos).
} 
A tragédia antiga - "espelho da Fatalidade" (TS, 267) -, é posta do avesso. As moscas é um drama cuja tensáo faz com que a necessidade ou o Destino presente nos textos gregos caminhe em sentido contrário. Consciente de que seu ato terá graves consequências, Orestes chama apenas para si a responsabilidade de seu crime. As rédeas de seu destino estão exclusivamente em suas próprias mãos, e não mais na dos reis e dos deuses. $\mathrm{O}$ próprio autor esclarece esse raciocínio com uma analogia: assim como Édipo é vítima de seu destino, Orestes é vítima de sua liberdade.

Para exprimir o perfil desse trabalho com o mito, devemos lançar mão da conferência apresentada em Nova Iorque, em 1946, em que Sartre considera os trabalhos dos jovens dramaturgos franceses - Anouilh, Camus e Beauvoir - no registro da forja. ${ }^{15}$ Esses autores não têm uma intenção em comum e o sentido de seus trabalhos é diferente; porém, eles estão de acordo nisto: não há uma natureza humana desde sempre dada, e o universal, agora, são as "[...] situaçôes nas quais os homens se encontram.” (TS, 59). Em relação a Orestes, poderíamos dizer que ele toma consciência de sua tarefa em um mundo em que as coisas já estavam dadas antes dele e que, todavia, ele ainda tinha algo a fazer. Orestes está em "[...] um mundo em que lhe é preciso jogar as cartas e correr seus riscos, ainda que isto lhe custe caro.” (TS, 59). Introduzindo no palco cênico personagens nessas condiçóes, o dramaturgo pode, então, "[...] iluminar os principais aspectos da condição humana e fazer o espectador participar da escolha livre que o homem faz nestas situaçóes.” (TS, 59). Sartre traz à tona personagens míticos cujas decisóes estão estreitamente ligadas ao destino das outras pessoas e à sua própria regra de conduta: "[...] o homem livre nos limites de sua própria situação, o homem que escolhe para todos os outros quando escolhe para si quer ele queira ou não- eis aí o tema de nossas peças." (TS, 61).

Esse teatro de situaçóes se inscreve na tradição de Corneille, para quem o teatro deve mostrar "[...] a vontade no próprio coração da paixão" e restituir "[...] o homem em toda sua complexidade, em sua realidade total." (TS, 62). Ao contrário de pintar um homem psicológico, como faz Racine, ao contrário do estudo dos caracteres próprios ao teatro psicológico, é preciso trabalhar com "[...] a representação de conflitos de direito" (TS, 62) em que "[...] os sistemas de valores, os sistemas morais e conceituais do homem se encontrem

${ }^{15} \mathrm{O}$ texto dessa conferência veio à tona pela primeira vez, em 1946, em uma revista americana Theatre arts - através de uma traduçáo de Rosamond Gilder, com o título: "Forgers of myths: the young playwrights of France". O texto que utilizamos e que está presente em Un théatrê de situations"Forger des mythes" - é uma retradução de Michel Contat. 
confrontados." (TS, 63). Sartre não deixa de lembrar que foi Hegel quem ensinou que "[...] a paixão nunca foi uma simples tempestade afetiva, mas, fundamentalmente, a afirmação de um direito." (TS, 61). Ora, todos esses jovens dramaturgos sabem que náo é possível distinguir, na vida de todos os dias, "[...] o fato do direito, o real do ideal, a psicologia da moral." (TS, 63). Como, entấo, se dirigir ao público, de tal modo que todos reconheçam suas inquietudes e preocupaçóes mais gerais apresentadas em cena? Esses jovens dramaturgos exprimem essas tensóes sob a forma de mitos que "[...] todos podem compreender e experimentar profundamente." (TS, 63). Através desses personagens bem conhecidos, o dramaturgo se dirige ao público, propondo-lhe situaçóes que preocupam todos os homens de uma determinada comunidade e época: são situaçóes em que todos eles se sentem concernidos. Por esse motivo, Orestes não pode ser um símbolo: ele é de carne e osso. Orestes também não é inteiramente prosaico: ele é um personagem mítico, no sentido em que "[...] o mal-entendido que o separa pode servir de encarnaçáo a todo o mal-entendido que separa o homem dele mesmo, do mundo, dos outros homens." (TS, 65).

Sartre faz questão de reconhecer a dívida dessa geração de dramaturgos também para com a tragédia clássica. Todos eles se valem de um procedimento muito conhecido: lançar mão da ação, no momento em que ela se dirige em direção à catástrofe. Desde a primeira cena, o conflito já se encontra em alta temperatura e prestes a atingir seu paroxismo. Além disso, o teatro desses jovens dramaturgos é "austero" e cria mitos: ele "[...] projeta ao público uma imagem engrandecida e enriquecida de seus próprios sofrimentos" (TS, 66); ele póe em cena "dramas breves e violentos" (TS, 67) centrados em conflitos de direito relativos a situaçóes muito gerais. Seu estilo é "claro e tenso ao extremo" (TS, 68); não tem muitos personagens e as situaçóes obrigam esses personagens a fazer uma escolha.

Este é o perfil do teatro de situações ou de ideias: ele não é um retorno à tragédia, já que ela foi um fenômeno que teve seu ápice entre os séculos XVI e XVIII; porém, Sartre adverte que todos esses dramaturgos estão "[...] menos preocupados em inovar do que retornar a uma tradição.” (TS, 58). O teatro de situações também não é teatro filosófico, no sentido em que ali pudesse haver alguma ilustração de teses filosóficas; porém, Sartre não deixa de lembrar que há uma historicidade dos problemas e que há muita diferença entre os problemas de antes e depois da guerra, tratados no teatro. $\mathrm{O}$ teatro de situaçôes não é um teatro de símbolos, mas um teatro de mitos austeros, 
uma vez que é rigoroso na investigação desses comportamentos humanos em situaçôes-limite, como, por exemplo, a morte, o exílio e o amor. O teatro de situaçôes é moral, porque discute questóes relativas ao sistema de valores de todos os homens. Ele é mítico, já que trabalha não com o símbolo, mas com o mito. Ele é ritual, visto que o que conta ali não é o indivíduo, mas as funções coletivas e sociais: o teatro é "[...] um grande fenômeno coletivo e religioso." (TS, 64). Sartre considera o teatro de situaçóes como uma resposta desses jovens dramaturgos à situaçáo concreta em que viviam sob a Ocupação e depois do fim da guerra. Esse teatro não repete cegamente uma tradição, nem é ilustraçáo de uma ideia preconcebida: “[...] o que ele tenta fazer é explorar a condição em sua totalidade e apresentar ao homem contemporâneo um retrato dele mesmo, seus problemas, suas esperanças e suas lutas." (TS, 63). ${ }^{16}$

Trabalhando com a liberdade no avesso da necessidade, Sartre concebe uma nova relação entre o destino e o homem. Vimos qual é a tradição em que essa peça se inscreve: ela continua ou prolonga alguns pontos da tragédia antiga e do teatro de Corneille, ela reivindica para si essa herança. Vimos, igualmente, que, com o teatro de situaçóes, algo novo se deu: com o tratamento do mito é a totalidade da realidade humana que está em questão. Ao invés de curvar-se sob o jugo do destino, ao invés da crença de que é vão lutar contra ele, Sartre mostra os caminhos trilhados por Orestes, na descoberta de sua liberdade. Orestes tem todo um futuro pela frente, enquanto ao seu homônimo grego cabe assumir seu destino prescrito pelos deuses. Em Ésquilo, a maldição do destino é implacável: "[...] se te marcou / o destino amargo, só te resta obedecer" (I, 194-95, 55), diz o Corifeu a Cassandra. O próprio Apolo diz a Orestes: "[...] fui eu mesmo, e mais ninguém, que te induzi / a ferir mortalmente a tua própria mãe." (III, 121-22, 150). A culpa de Orestes

\footnotetext{
${ }^{16}$ Em uma entrevista de 5 de janeiro de 1959, Sartre faz um contraste elucidativo a propósito da relação existente entre a filosofia e o teatro. Para ele, a peça de teatro é "[...] a forma mais apropriada, hoje, para mostrar o homem em ato"; já a filosofia deve se ocupar justamente desse homem aí: "[...] é por isto que o teatro é filosófico e que a filosofia é dramática” (SARTRE, 1984, p. 109). Para aprofundar o sentido dessa relação, sugerimos a interpretação de Silva. Na Introdução de seu livro, ele nos diz que, para compreender a especificidade e a originalidade da obra de Sartre, é preciso levar em consideração duas coisas: em primeiro lugar, "[...] certo projeto de pensar a ordem humana: a compreensão da existência como condiçâo e da contingência como o seu horizonte-limite"; em segundo lugar, "[...] o ajuste característico do projeto sartriano de pensar a ordem humana [...]: entendemos que o centro de irradiação desse projeto determina a relação entre filosofia e literatura [e por extensão também o teatro] como vizinhança comunicante, e é responsável pela diferença e pela adequação recíproca dos dois modos da dualidade expressiva. Com isto queremos dizer que a expressão filosófica e a expressão literária são ambas necessárias em Sartre, porque, por meio delas, o autor diz e não diz as mesmas coisas." (SILVA, 2004, p.12).
} 
é “involuntária e inevitável”. (JAEGER, 2001, p. 306). Ela é involuntária, porque Orestes obedece Apolo, e inevitável, porque efetivamente ele realiza o crime de que é acusado. Em outra peça de Ésquilo (1992, p. 56-57), Prometeu explica que "[...] o engenho é, de longe, mais fraco do que a Necessidade" e que nem mesmo Zeus pode "[...] fugir ao que está marcado pelo destino". ${ }^{17}$

Orestes, segundo Sartre, deve assumir e transformar seu destino através de uma ação mediada pelos outros homens. Sua ação é livre na exata medida em que ela é limitada por sua situação. Esse mito é um mito da liberdade e da libertação, ele é a invenção de um homem que se libertou e libertou seus concidadáos dos caprichos do destino cego, da falsa concepção de liberdade e do peso do passado morto. Sartre quer que o espectador, sob a Ocupação, resista; é ali que ele forja seu ferro em brasa. Seu personagem coloca em questão o destino e dá outro sentido para a ação humana. Ora, Egisto também colocou o seu destino e o do povo em questáo. Para manter a ordem, ele inventou fábulas e instituiu a festa dos mortos a fim de incutir o arrependimento nos cidadãos de Argos. Orestes, por sua vez, conta a fábula do flautista e dos ratos. A diferença está no modo de utilização da imaginação, já que ela pode inventar superstiçôes que instauram a servidáo, ou criar mitos que discutam e estimulem a liberdade e o reconhecimento do outro. Sob a Ocupação nazista, Sartre dissemina uma mensagem de liberdade e libertação, mas também póe em relevo a importância do engajamento necessário para o ato livre e suas repercussóes coletivas e sociais.

Orestes não termina a peça assassinado pelos guardas de Egisto ou linchado pelo povo: ele não se entrega como Electra. Orestes diz a Electra: "Do outro lado dos rios e das montanhas há um Orestes e uma Electra que nos esperam. Será preciso procurá-los pacientemente.” (M, 108). Mas sua irmã

\footnotetext{
${ }^{17}$ Esquilo (1992, p.56-57). Como compreender essa "Necessidade" ou a Ananke presente no texto de Ésquilo? Rivier nos dá várias pistas: ela não é uma necessidade causal, no sentido de que uma causa física produz seu efeito, também não é uma necessidade no sentido lógico ou metafísico; os atos de Orestes não são determinados por uma lei preestabelecida. A necessidade em Ésquilo é "[...] o peso da crença e da reverência que se liga ao objeto supremo de uma religiáo em que o sagrado é ainda o lugar do tremendum"; ela é "[...] a força com a qual, em Ésquilo, o homem é requerido pelos deuses, a insistência com a qual, em uma situação dada, os deuses lhes fazem valer algumas exigências." Quanto à decisão responsável, Rivier salienta que, em Ésquilo, ela não é fundada em uma escolha de possibilidades. A decisão responsável de Orestes se funda "[...] sobre a aceitação de uma 'necessidade', isto é, sobre a aceitação de uma ordem que se impóe pelo fato de que ela existe, e não em virtude de sua conformidade com uma norma ou unicamente pelas razóes que um sujeito pode ter para subscrevê-la. Ela náo é o ato de um sujeito autônomo no sentido kantiano, até mesmo tomista, mas de um sujeito que deve contar imediatamente com seus deuses assim como os próprios deuses podem contar com esses sujeitos" (RIVIER, 1968, p.38-39, grifo nosso).
} 
se recusa a escutar e pede socorro a Júpiter, rogando para que ele a defenda das moscas, do seu irmão e de si mesma. Electra decide consagrar sua vida inteira à expiação de seu crime, outorgando a Júpiter as rédeas de seu destino: "[...] seguirei tua lei, serei escrava e coisa tua, beijarei teus pés e teus joelhos." (M, 108). Já Orestes não apenas segue seu caminho como abre os olhos do povo: ele se faz no interior e pela história de Argos, virando do avesso o procedimento da tragédia antiga. A força do teatro sartriano nasce do interior da própria situação, ela nos faz ver a reinvenção do mito de Orestes. Se Orestes não se curva nem à superioridade dos deuses, nem à imobilidade dos valores do passado, é porque ele mesmo constrói seu próprio caminho, ele atribui essa responsabilidade apenas a si mesmo.

O trabalho com o mito - a forja de mitos - se faz sempre a partir de um material previamente dado. Portanto, não podemos falar de ruptura radical, nem de criação ex nihilo: há uma retomada e uma construção do mito, as quais invertem seu sentido tradicional. Tanto o personagem quanto o arcabouço da peça são os mesmos da tradição, mas o trabalho no avesso da necessidade, isto é, o trabalho com a conduta livre de Orestes, reinventa o mito. Como entender essa posição de Sartre em relação à tradição? Penso que poderemos compreender o lugar da filosofia sartriana e o seu modo de operação a partir de algumas sugestóes da pesquisa atual sobre o autor. Souza (2014), por exemplo, deixa claro o que está em questão aqui ao defender a ideia de que Sartre parte da tradição com a intenção de sair dela. Para nós, é esse raciocínio que devemos encontrar operando sob o trabalho da forja de mitos. Sartre, ao mesmo tempo, conserva e sai da tradição. Difícil relação, porque ela consiste em abordar as questôes mais atuais conservando as aquisições tradicionais. Segundo Souza, Sartre mantém a tensão entre a tradição e o mundo contemporâneo: "[...] nunca total indistinção entre os termos e nunca total separação entre eles.”(SOUZA, 2014, p. 109). Esse pensamento nos ajuda a entender o sentido da ação de Orestes fazendo-se ali na tensão entre o passado e o futuro. Ao submeter Orestes a uma situação-limite e investigando o sentido de sua ação, de seu comportamento, Sartre subverte a tradição do mito antigo presente na tragédia: ao abordar essa tradição, na contracorrente, cometendo um contrassenso, ele dá a ver um novo Orestes.

Através do trabalho com algo que aparentemente não passa de um anacronismo, o mito, há um profundo debate sobre o mundo atual. É essa questão de horizonte que Silva nos ajuda a reconhecer nesse drama sartriano (SILVA, 2003). Sartre opera, nessa peça, com "[...] certo cruzamento entre o 
anacronismo e a atualidade", (SILVA, 2003) o qual se manifesta de diversas formas, quando colocamos em contraste Argos sob a dominação de Egisto e Paris sob a Ocupação nazista. Esse cruzamento se dá quanto ao lugar, ao tempo, à dimensão coletiva, ao indivíduo e à liberdade. Ora, para compreender o drama de Orestes sob essas circunstâncias ou o sentido de sua ação em uma determinada situação, é preciso ouvir através de sua boca um apelo ainda atual à liberdade. Quanto à transformação da relação antiga entre história e destino, é preciso dizer que, agora, o ato livre de Orestes concebido por Sartre nos mostra que a experiência é imprescindível e que o passado nunca pode faltar, já que é sempre nosso ponto de partida. O processo de construção que Sartre preconiza para a experiência do mundo atual náo exclui o passado; mais ainda: é esse processo que torna abstrata a ditadura do sempre novo ou do novo a qualquer preço. Durante a Ocupação, Orestes veio disseminar uma mensagem de construçấo de um futuro novo que não abre mão do passado. $\mathrm{O}$ futuro que Orestes fez raiar exigiu não só o seu passado no interior de sua família, mas também o passado da natureza, do povo, da cidade, dos reis e dos deuses. Quando Orestes diz ao povo "tentai viver" é porque se trata, para os cidadãos de Argos, da possibilidade de construir outra Argos e outra relação entre os cidadãos: eles devem tentar ser livres!

Em As moscas, essa vida nova que está por se viver nunca poderá ser considerada fora desse contexto. É essa relação que devemos matizar para compreender o sentido dessa peça. Silva nos ajuda a perceber o que está em jogo nessa tensão ao evidenciar que a atualidade se destaca sempre sobre um fundo de anacronismo que jamais pode ser afastado. ${ }^{18}$ Isso pode ser visto através de Orestes imaginado e posto em cena por Sartre. Isso nós também podemos ver no próprio diálogo que o livro As moscas enceta com uma determinada tradição do teatro. Resta que é preciso ver, na convergência da atualidade de Argos e de Paris sob a Ocupação, algo que ainda nos diz respeito, já que a atualidade dessa peça talvez esteja nesse apelo dirigido ao leitor e ao espectador: seja livre e assuma a responsabilidade e as consequências de suas açôes. Orestes nos ajuda a matizar o papel do passado, ele também nos ajuda a perceber no presente a presença do que já passou. Enfim, Orestes nos mostra não só como valorizar o passado para irmos além dele, como também nos dá

18 "O sentido de nossa experiência presente”, diz Silva (2003), “[...] somente se constrói em relaçấo ao passado, seja para reiterá-lo, seja para negá-lo, seja para fazer dele o ponto de partida para a construção de um outro tempo. O presente sem passado é uma abstração; a atualidade se destaca no que tem de original sobre o fundo de inatualidade sempre presente, e que constitui o critério para que possamos assumir a nossa diferença histórica." (grifo nosso). 
a pensar sobre qual é o lugar que é preciso atribuir a nossas aquisiçóes. Para ver isso com relativa clareza, vale a pena ler ou ver a peça tendo em mente este pensamento de Silva (2003): "[...] somos atuais a partir do que os outros foram no passado e que já não somos mais; no entanto isto que já não somos está incorporado à nossa maneira de ser e nos ajuda a entender o que somos". Nessa peça, Sartre focaliza alguém que questiona o alcance de suas açôes e que considera uma possibilidade de construção. Ele nos dá a ver um Orestes que não tem um saber prévio dos caminhos que vai trilhar, mas que, mesmo assim, caminha. Por isso mesmo, no seu próprio desenrolar, a peça exige de nós algo que ela concretiza sob nossos olhos: uma consciência mais crítica na difícil escolha dos caminhos que vamos tomar para construir nossas vidas. Escolha livre que não escapa à existência.

CARDIM, Leandro Neves. The forge of myth in The Flies of Sartre. Tans/form/ação, Marília, v. 40, n. 4, p. 167-186, Out./Dez., 2017.

\begin{abstract}
The aim of the present article is to shed some light on how Sartre recreates Orestes myth in his play The flies. Sartre show us that his dialogue with the tradition works with freedom as the other side of necessity, which leads to the inversion of tradition. He works with such a conception of the relation between past and present which enable us to consider Orestes in a way that the past is not excluded; on the contrary, it is demanded. Orestes is not out of nowhere, and at the same time his actions are not simply the continuation of the past. The present article intends to analyze the role played by the past in Sartre's The flies, as well as to point, from this particular standpoint, the place off human acquisitions should have in our present world.
\end{abstract}

KEYWORDS: Sartre. Theater. Myth. Tradition. Actuality.

\title{
REFERÊNCIAS
}

BACHOFEN, J. J. Le droit maternel: recherche sur la gynécocratie de l'antiquité dans la nature religieuse et juridique. Tradução de Étienne Barilier. Paris: L'Age d'Homme, 1996.

BLANCHOT, M. Le mythe d'Orestes. In: Faux pas. Paris: Galimard, 1971.

DOSTOIEVSKI, F. Os irmãos Karamázov. Tradução de Paulo Bezerra. São Paulo: Ed.34, 2008.

ÉSQUILO. Prometeu agrilhoado. Tradução de Ana Paula Quintela. Lisboa: Ed.70, 1992.

Oresteia: Agamêmnon, Coéforas, Eumênides. Tradução de Mário da Gama Kury.

Rio de Janeiro: Zahar, 2010.

GRIMAL, P. Dicionário da mitologia grega e romana. Traduçáo de Victor Jabouille. Rio de Janeiro: Bertrand Brasil, 2011. 
JAEGER, W. Paidéia: a formação do homem grego. Tradução de Artur Parreira. São Paulo: Martins Fontes, 2001.

MERLEAU-PONTY, M. Les Mouches. In: Parcours 1935-1951. Lagrasse: Verdier, 1997. p. 61-64.

NOUDELMANN, F. Huis clos et les mouches de Jean-Paul Sartre. Paris: Gallimard, 1993. RIVIER, A. Remarques sur le "nécessaire" et la "nécessité" chez Eschyle: Revue des Études Grecques. t. 81, n. 384/385, p. 36, jan./jun. 1968.

SARTRE, J.-P.Huis clos: suivi de les mouches. Paris: Gallimard, 1947. . Situations III. Paris: Gallimard, 1949.

L. Les carnets de la drôle de guerre. Novembre 1939 - Mars 1940. Paris: Gallimard, 1983. . Jean-Paul Sartre [Entrevista]. In: Chapsal, M. Envoyer la petite musique. Paris: Grasset \& Fasquelle, 1984. . Qu'est-ce que la littérature?Paris: Gallimard, 1985. . Un théatre de situations. Paris: Gallimard, 1992. . As moscas. Tradução de Caio Liudvik. Rio de Janeiro: Nova Fronteira, 2005. SILVA, F. L.Humanidades: anacronismo e atualidade.Revista Existo.com/\#2 Revista eletrônica do grupo de pós-graduação do FiloCom. Núcleo de estudos filosóficos da comunicação. ECA-USP: São Paulo, set./out./nov./dez. 2003. Disponível em: <http://www. eca.usp.br/nucleos/filocom/existocom/especial2.html>. Acesso em: 10 jul. 2015. . Ética e literatura em Sartre: ensaios introdutórios. São Paulo: Editora UNESP, 2004.

SOUZA, T. M. O lugar incompreensível (e fundamental) de Sartre entre a filosofia moderna e a filosofia contemporânea. In: CARDIM, L. N. (Org.). Tópicos de filosofia francesa contemporânea. Curitiba: Editora UFPR, 2014. p. 99-110.

VERNANT, J.-P. Lendas do matricídio. In: . Entre mito e política. Tradução de Cristina Muracho. São Paulo: EDUSP, 2009. p. 277-280.

Recebido em 09/09/2015

Aceito em 15/10/2016 